\title{
PENINGKATAN LITERASI FINANCIAL TECHNOLOGY BAGI SANTRI ZAMAN NOW DAN PENGASUH PONDOK PESANTREN DALAM MENGHADAPI ERA REVOLUSI INDUSTRI MELALUI PENANAMAN NILAI DALAM KELAS INSPIRASI
}

\author{
Fachrurrozie, Agus Wahyudin, Ahmad Nurkhin, dan Hasan Mukhibad \\ Fakultas Ekonomi, Universitas Negeri Semarang \\ E-mail : fachrurais@mail.unnes.ac.id
}

\begin{abstract}
ABSTRAK
Pondok pesantren telah menjadi Lembaga penyelenggara Pendidikan agama yang sangat dibutuhkan oleh masyarakat. Perkembangan di dunia bisnis dan teknologi yang perlu dipahami oleh santri zaman now adalah financial technology atau lebih akrab dikenal dengan sebutan fintech atau tekfin (teknologi finansial). Fintech telah menjadi pokok bahasan hangat di kalangan masyarakat. Santri tidak boleh bingung tentang fintech. Di samping itu, terdapat term lain yang perlu dipahami oleh santri zaman now, diantaranya startup, unicorn, blockchain, bitcoin, ecommerce, market place, dan lain sebagainya. Dengan demikian, santri akan mampu memahami fenomena yang berkembang, baik dalam perspektif ilmu agama maupun ilmu ekonomi dan bisnis. Tim pengabdian kepada masyarakat Fakultas Ekonomi Universitas Negeri Semarang menganggap pentingnya memberikan pemahaman kepada santri zaman now tentang perkembangan fintech tersebut. Kelas Inspirasi merupakan upaya yang akan dilakukan oleh tim pengabdian. Melalui kelas Inspirasi, santri akan memperoleh pengetahuan, pengalaman, dan keterampilan untuk memahami fintech dan perkembangan teknologi lainnya. Melalui kelas Inspirasi, santri juga akan memperoleh pengalaman mengenai ide bisnis dan penanaman nilai "santri" dari pakar dan praktisi. Kegiatan pengabdian telah dilaksanakan dalam dua kali pertemuan. Pertemuan pertama telah dilaksanakan di pondok pesantren Al Asror Kelurahan Patemon Gunungpati Kota Semarang. Materi yang disampaikan adalah perkembangan financial technology dan pentingnya manfaat fintech dan kasus-kasus yang terjadi mengenai pemanfaatan fintech. Pertemuan kedua dilaksanakan di Rumah Darin Kelurahan Pakintelah Kecamatan Gunungpati Semarang. Materi yang disampaikan adalah pentingnya kompetensi wirausaha bagi santri zaman now. Peserta kegiatan pengabdian dapat mengikuti dengan baik.
\end{abstract}

Kata Kunci: financial technology, literasi, santri zaman now, kelas inspirasi

\section{PENDAHULUAN}

Pondok pesantren telah menjadi lembaga penyelenggara pendidikan agama yang sangat dibutuhkan oleh masyarakat. Pondok pesantren diharapkan mampu melahirkan santrisantri yang akan menjadi agent of change di masyarakat. Ia akan menjadi warga yang mampu menuntun warga lainnya untuk menjadi warga negara yang taat beragama dan menjadi warga negara yang cinta tanah air dan negerinya. Pembentukan karakter santri menjadi sangat penting untuk 
diperhatikan, terlebih jika dikaitkan dengan perkembangan zaman. Santri akan menghadapi tantangan yang berat jika tidak mampu mengikuti dan beradaptasi.

Solkan (2017) menyebutkan bahwa santri adalah sebutan bagi orang yang belajar ilmu agama. Walaupun demikian, santri masih dianggap sebelah mata, dianggap kaum kolot, tertinggal ilmu pengetahuannya, tradisional, dan hanya sibuk mengurus agama saja. Padahal, santri merupakan penopang bangsa yang perannya tidak dapat dilupakan begitu saja, terkait dengan perjalanan sejarah bangsa Indonesia. Santri telah berkontribusi dalam upaya meraih kemerdekaan.

Santri zaman now menjadi sebutan paling tepat, agar santri tidak dianggap ketinggalan zaman. Banyak bukti yang menunjukkan bahwa santri telah mampu mengikuti perkembangan teknologi dan ilmu pengetahuan. Santri zaman now bisa menjadi juara dalam kontes robot di Jepang. Banyak santri yang telah berhasil menjadi entrepreneur, penulis, dan lain sebagainya. Santri telah mampu menghadapi zaman yang kian mengglobal, termasuk revolusi industri 4.0 .
Namun demikian, perkembangan teknologi sangat cepat. Menurut KH Ma'ruf Amin, santri di masa yang akan datang diharapkan memberikan jalan keluar atas kondisi dan problem yang terjadi saat ini. Tantangan yang dihadapi santri saat ini sangat berat. Santri diharuskan menguasai digital, termasuk belajar ilmu siasat ekonomi dan kebudayaan (nu.or.id). lebih lanjut ia menjelaskan bahwa kemandirian di zaman global di antaranya bisa tercapai dengan penguasaan teknologi dan penguatan bidang-bidang ekonomi, terutama pemberdayaan.

Pendapat yang sama juga disampaikan oleh Rektor IAIN Salatiga, santri di masa sekarang diharapkan dapat melanjutkan berjuang menyiarkan Islam, dan santri harus siap menjadi pewaris bangsa yang sah dari perjuangan bangsa. Santri diharapkan menyiapkan dari sekarang untuk menjawab tantangan di masa depan dengan menyiapkan untuk menjadi ilmuan atau entrepreneur. Di samping itu, ketika santri harus mempunyai prestasi dan prihatin dalam menuntut ilmu di perguruan tinggi mana pun ketika menjadi mahasiswa (iainsalatiga.ac.id).

Perkembangan di dunia bisnis dan teknologi yang perlu dipahami oleh 
santri zaman now adalah financial technology atau lebih akrab dikenal dengan sebutan fintech atau tekfin (teknologi finansial). Fintech telah menjadi pokok bahasan hangat di kalangan masyarakat. Santri tidak boleh bingung tentang fintech. Di samping itu, terdapat term lain yang perlu dipahami oleh santri zaman now, diantaranya startup, unicorn, blockchain, bitcoin, ecommerce, market place, dan lain sebagainya. Dengan demikian, santri akan mampu memahami fenomena yang berkembang, baik dalam perspektif ilmu agama maupun ilmu ekonomi dan bisnis.

Perkembangan fintech di Indonesia sendiri bisa dibilang sangat subur. Diperkirakan mulai muncul pada tahun 2006, pada tahun 2017 industri fintech Indonesia memiliki nilai transaksi sebesar US\$15,02 miliar (Rp202,77 triliun) tumbuh $24,6 \%$ dari tahun sebelumnya. Perkembangan fintech di Indonesia telah merambah ke berbagai sektor, mulai dari startup pembayaran, peminjaman (lending), perencanaan keuangan (personal finance), investasi ritel, pembiayaan (crowdfunding), remitansi, riset keuangan, dan lain-lain (dbs.com). salah satu penyebab pesatnya perkembangan fintech adalah generasi millennials yang merupakan generasi dengan semangat entrepreneur sangat tinggi. Generasi millennials memilih fintech sebagai bisnis karena peluangnya masih sangat tinggi dan fintech masih tergolong baru.

Bentuk aplikasi fintech di dunia diantaranya di bidang pembayaran dan transfer, pinjaman dan pembiayaan, financial management, asuransi, serta markets \& exchanges (Iman, 2016). Ia menyebutkan bahwa aplikasi fintech di segmen payment merupakan segmen yang paling besar saat ini di Indonesia. Aplikasi payment sangat banyak seperti doku, t-cash, paytren, dana, go-pay, ovo, dan lain sebagainya. Fintech sangat berperan dalam ekonomi di Indonesia, di antaranya memberi solusi struktural bagi pertumbuhan industri berbasis elektronik (e-commerce) dan mendorong pertumbuhan usaha kecil dan menengah serta lahirnya wirausahawan (entrepreneur) baru.

Ketua Harian Asosiasi Financial Technology (AFTECH) Indonesia Kuseryansyah menyebutkan, potensi perkembangan industri fintech di Tanah Air masih besar. Salah satunya disebabkan oleh masih rendahnya tingkat adopsi fintech masyarakat, yakni di bawah sembilan persen. Kuseryansyah menjelaskan, nilai 
tersebut lebih rendah dibanding dengan negara di Asia. Tingkat adopsi fintech di Singapura mencapai 23 persen, India sekitar 70 persen dan Cina menyentuh angka 80 persen (republika.co.id). Kuseryansyah menjelaskan, banyak isu yang mempengaruhi tingkat adopsi fintech suatu negara. Di antaranya jaringan internet dan kepemilikan ponsel pintar. Kunci berikutnya adalah harga layanan yang murah dan terjangkau. Terakhir, sosialisasi produk dari suatu perusahaan hingga bisa terdengar dan dipahami oleh masyarakat.

Tim pengabdian kepada masyarakat Fakultas Ekonomi Universitas Negeri Semarang menganggap pentingnya memberikan pemahaman kepada santri zaman now tentang perkembangan fintech tersebut. Di samping itu, tim pengabdian juga akan memberikan penguatan santri zaman now. Kelas Inspirasi merupakan upaya yang akan dilakukan oleh tim pengabdian. Melalui kelas Inspirasi, santri akan memperoleh pengetahuan, pengalaman, dan keterampilan untuk memahami fintech dan perkembangan teknologi lainnya. Melalui kelas Inspirasi, santri juga akan memperoleh pengalaman mengenai ide bisnis dan penanaman nilai "santri" dari pakar dan praktisi.
Topik ini sangat relevan terhadap perkembangan santri dan pengasuh pondok pesantren. Banyak tim pengabdian yang telah melakukan kegiatan pengabdian kepada masyarakat di pondok pesantren. Topik kewirausahaan menjadi tema yang menarik dan cukup sering disampaikan oleh tim pengabdian dari berbagai kampus. Ghofirin \& Karimah (2017) melaksanakan kegiatan pengabdian di pondok pesantren Qomaruddin Gresik dengan topik kewirausahaan. Mutiah (2015) melaksanakan kegiatan pelatihan pembuatan permen rempah jahe untuk meningkatkan keterampilan santri di lingkungan pondok pesantren terpadu $\mathrm{Al}$ Yasini Pasuruan. Kardoyo et al. (2018) melaksanakan kegiatan Ipteks bagi Masyarakat (IbM) bagi santri di kecamatan Gunungpati Kota Semarang untuk meningkatkan minat berwirausaha. Nurkhin et al. (2020) memberikan pelatihan untuk peningkatan kompetensi wirausaha halal food bagi santri tahfidz.

Khoirudin et al. (2017) mengambil topik peningkatan kemampuan membuat video animasi stop motion bagi santri Pondok Pesantren Al Ishlah Tugu Semarang dalam kegiatan pengabdiannya. Fakultas Sains dan 
Teknologi Informasi melakukan kegiatan pengabdian di Pondok Pesantren Qotrun Nada Depok dengan topik Pengenalan Sains dan Teknologi Pembelajaran. Zulfikar \& Mayvita (2018) melaksanakan pengabdian dengan topik diversifikasi Produk olahan berbasis ikan patin sebagai potensi usaha bagi Panti Asuhan Al Amin dan Sultan Suriansyah Banjarmasin. Wakit \& Huda (2018) mengambil judul pengabdian "pemberdayaan santri pondok pesantren tradisional (pemanfaatan teknologi komputer dalam pembelajaran kitab kuning). Ekaningsih melaksanakan kegiatan pelatihan membangun kemauan dan ketertarikan berpidato Bahasa Inggris bagi warga Ponpes Satu Atap Nurul Amal Kenteng Bandungan Kabupaten Semarang. Wahidah (2018) melaksanakan kegiatan pelatihan manajemen kalbu di pondok pesantren putri Hidayatullah Bojonegoro.

Terdapat beberapa pondok pesantren di Kecamatan Gunungpati Kota Semarang. Di daerah lingkar Universitas Negeri Semarang lebih dari 5 pondok pesantren yang telah berdiri cukup lama, diantaranya pondok pesantren Al Asror, Al Uswah, Kalialang, Durrotu Aswaja, Rijalul
Quran, dan lain sebagainya. Pondok Pesantren tersebut menyelenggarakan pendidikan agama dan menerima santri sejak usia sekolah dasar. Santri berasal dari berbagai daerah di Jawa Tengah dan terdapat santri dari luar Jawa. Terdapat juga pondok pesantren yang menyelenggarakan sekolah formal (MTs, MA, SMK), namun sebagian besar adalah pesantren tradisional. Dengan demikian, pondok pesantren membutuhkan kerja sama pihak kampus (UNNES) untuk meningkatkan kapasitas santri, khususnya di bidang teknologi dan bisnis.

Salah satu pengasuh pondok pesantren, KH Almamnukhin Kholid, berpendapat bahwa keadaan santri saat ini cukup berbeda. Santri harus menghadapi tantangan berat di bidang teknologi, khususnya smartphone dan internet. Jika tidak bisa mengendalikan diri, maka santri akan terjerumus dalam game online dan konten negatif dari internet. Di samping itu, santri saat ini juga harus digenjot kreativitasnya dalam bidang bisnis. Banyak pengasuh yang memberikan contoh langsung dengan berbisnis. Harapannya, santri tidak akan kaget dan akan cepat beradaptasi ketika melalui kehidupan sesungguhnya di masyarakat. 
Pelaksanaan kegiatan pengabdian dengan topik financial technology dan penanaman nilai dalam kelas inspirasi diharapkan dapat memberikan dampak positif kepada santri. Santri akan memperoleh bekal dalam memanfaatkan teknologi dan internet. Di samping itu, santri akan memperoleh sharing moment dari para pakar dan motivator agar bisa meraih sukses di masa yang akan datang.

Berdasarkan uraian analisa situasi dan permasalahan mitra, maka rumusan masalah pada kegiatan pengabdian masyarakat ini adalah sebagai berikut;

Bagaimana meningkatkan literasi financial technology bagi santri zaman now dan pengasuh pondok pesantren melalui penanaman nilai dalam Kelas Inspirasi?

\section{METODE PELAKSANAAN}

Penyelenggaraan Kelas Inspirasi adalah metode utama dalam kegiatan pengabdian masyarakat ini. Materi yang disampaikan dalam kegiatan pengabdian ini adalah financial technology, success story, motivasi bisnis, dan lain sebagainya. Dalam Kelas inspirasi digunakan berbagai teknik penyampaian materi kepada santri dan pengasuh pondok pesantren. Tim pengabdi berkolaborasi dengan beberapa pihak untuk menjadi narasumber dalam Kelas Inspirasi. Bentuk kegiatan dalam Kelas Inspirasi diantaranya adalah sosialisasi financial technology, seminar motivasi, moment sharing, success story class, dan lain sebagainya. Santri akan memperoleh banyak pengalaman dari penyelenggaraan Kelas Inspirasi.

Pelaksanaan kegiatan pengabdian harus dirancang dengan baik, agar kegiatan pengabdian dapat berjalan dengan lancar serta menghasilkan manfaat bagi santri khususnya. Tahapan pelaksanaan kegiatan pengabdian adalah sebagai berikut;

1. Tahapan Persiapan

Persiapan yang dilaksanakan adalah menjalin komunikasi intensif dengan pengelola pondok pesantren dan narasumber yang akan diajak kolaborasi dalam penyelenggaraan Kelas Inspirasi. Pondok pesantren yang akan menjadi mitra utama dalam kegiatan pengabdian adalah Ponpes Al Asror Patemon. Tim pengabdi telah menjalin hubungan yang baik selama ini dan memiliki santri yang sangat heterogen. Sedangkan narasumber utama selain Ponpes Al Asror adalah Otoritas Jasa Keuangan (OJK) Regional Jateng dan DIY. Tim pengabdi juga telah 
memiliki hubungan yang baik dengan OJK. Dengan demikian akan memperlancar kegiatan kerjasama. OJK juga sangat kapable dalam bidang financial technology. Tim pengabdi akan bersama-sama OJK, Ponpes Mitra, dan mitra lainnya untuk memberikan yang terbaik dalam penyelenggaraan Kelas Inspirasi. Tim pengabdi juga akan mengajak alumni UNNES dan Ponpes untuk memberikan materi sharing moment atau success story.

2. Tahapan Pelaksanaan

Setelah persiapan kegiatan dapat terkoordinasi dengan baik, maka tahapan berikutnya adalah pelaksanaan. Penyelenggaraan kelas inspirasi diawali dengan penyelenggaraan seminar financial technology dengan menghadirkan OJK dan tim pengabdi sebagai narasumber utama. KH. Almamnukhin Khalid (PP Al Asror) menjadi keynote speaker dan mengawali diselenggarakannya Kelas Inspirasi. Kegiatan pengabdian dalam Kelas Inspirasi akan dilaksanakan minimal 2 kali pelaksanaan. Dan harapannya akan memberikan dampak positif bagi santri untuk mampu menghadapi perkembangan jaman dengan lebih memahami teknologi, internet, dan wirausaha.

3. Tahapa Evaluasi

Kegiatan evaluasi dilaksanakan secara bersamaan dengan tahapan kegiatan pengabdian lainnya. Artinya kegiatan evaluasi dimulai dari tahapan persiapan. Namun, kegiatan evaluasi ini difokuskan pada evaluasi menyeluruh pelaksanaan kegiatan pengabdian.

Kegiatan pengabdian ini dikatakan berhasil jika; (1) telah berhasil melaksanakan kelas Inspirasi minimal $75 \%$ dari jumlah rencana yang akan dilaksanakan; (2) kelas Inspirasi mampu menghadirkan narasumber dari kolaborasi tim pengabdi dan pondok pesantren; dan (3) menghasilkan modul pengenalan financial technology, success story, dan menjadi santri zaman now.

\section{HASIL PENGABDIAN DAN \\ PEMBAHASAN}

Hasil Pelaksanaan Kegiatan Pengabdian

Kegiatan pengabdian ini telah dilaksanakan dalam dua pertemuan. Pertemuan pertama dilaksanakan pada Ahad, 23 Juni 2019 di Pondok Pesantren 
As Salafy Al Asror Kelurahan Patemon Kecamatan Gunungpati Kota Semarang. Pengabdi menyajikan materi mengenai perkembangan financial technology di Indonesia khususnya. Di samping itu, permasalahan dan kasus yang terjadi juga menjadi materi yang disampaikan. Dr. Agus Wahyudin, M.Si. menyajikan materi tersebut. Kegiatan diikuti oleh santri sejumlah 30 orang dimulai pukul 09.00 wib sampai dengan pukul 12.00. Perkembangan financial technology yang pesat di Indonesia menjadi topik yang hangat didiskusikan oleh tim pengabdi dan santri. Tidak banyak santri yang cukup memahami perkembangan fintech dan kasus-kasus yang terjadi di Indonesia. Santri diharapkan dapat berhati-hati dalam memanfaatkan jasa fintech, khususnya peer to peer landing yang telah banyak memakan korban.

Peserta pengabdian mengikuti dengan baik penjelasan yang disampaikan oleh tim pengabdi. Tim pengabdi menggunakan metode ceramah diskusi dan tanya jawab dalam memaparkan materi. Interaksi secara langsung membuat kegiatan menjadi lebih menarik. Peserta dapat mengajukan pertanyaan secara langsung dan pemateri juga langsung melakukan sesi tanya jawab kepada peserta.
Pertemuan kedua dilaksanakan pada tanggal 7 Juli 2019 di Rumah Darin Kelurahan Pakintelan Kecamatan Gunungpati Kota Semarang. Drs. Fachrurrozie, M.Si. dan Dr. Agus Wahyudin, M.Si. memaparkan materi mengenai pentingnya berwirausaha di masa yang akan datang. Santri juga dituntut untuk dapat bersikap kreatif dalam menghadapi tantangan zaman. Materi dasar kewirausahaan disampaikan dengan baik oleh Drs. Fachrurrozie, M.Si. dilanjutkan true story dari Dr. Agus Wahyudin, M.Si. tim pengabdi sekaligus owner Rumah Darin bersama ibu Rachmawati. Materi yang disampaikan adalah perjalanan bisnis Rumah Darin bersama istri.

Kegiatan pengabdian ini diikuti santri yang telah mengikuti kegiatan pengabdian pada pertemuan kedua, sebanyak 20 santri. Kegiatan diawali dengan sambutan tuan rumah, owner Rumah Darin dan dilanjutkan dengan paparan materi. Peserta diajak memahami pentingnya berwirausaha dan diberikan contoh konkret pelaku usaha, dalam hal ini owner Rumah Darin yang melakukan usaha di bidang cake and bakery. Rumah Darin adalah pelaku usaha dengan produk utama Pie Susu 
Darin dan telah memasarkan produknya ke beberapa wilayah di Jawa Tengah.

Peserta cukup menikmati paparan pemateri, khususnya dalam mendegarkan perjalanan nyata dari owner Rumah Darin. Peserta tampak bersemangat bertanya tentang bagaimana menjadi wirausaha yang sukses dan bagaimana memulainya. Pemateri menjelaskan dengan sistematis dan memberikan inspirasi bagi peserta. Harapannya, santri dapat mengeksplorasi kemampuan diri dan potensi yang ada di lingkungan sekitar untuk dapat menjalankan usaha.

Berikut adalah dokumentasi pelaksanaan kegiatan.

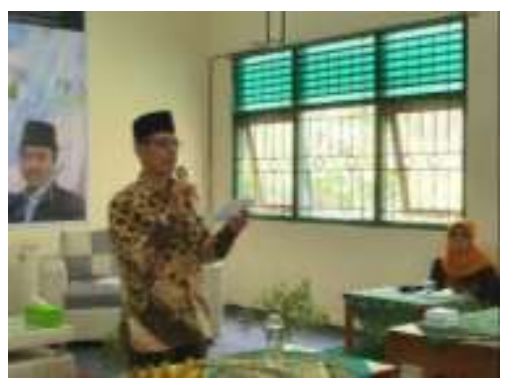

Tim Pengabdi sekaligus Narasumber menyampaikan materi

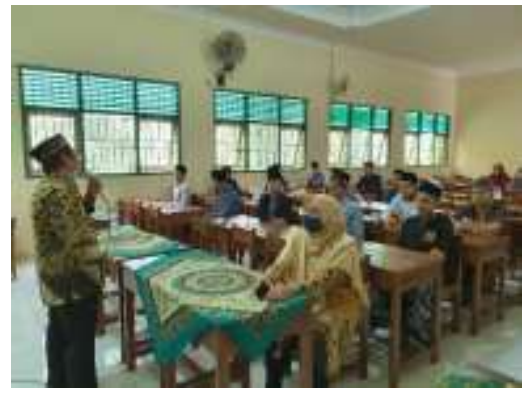

Narasumber menyampaikan materi

\section{Evaluasi Pelaksanaan Kegiatan Pengabdian}

Kegiatan pengabdian kepada masyarakat ini telah dilaksanakan dengan baik. Evaluasi juga telah dilaksanakan dengan uraian sebagai berikut;

a. Evaluasi pra-kegiatan. Perencanaan kegiatan dapat terlaksana dengan baik. Koordinasi yang baik dengan mitra (Pondok Pesantren dan Rumah Darin) menjadi kunci kelancaran persiapan pelaksanaan kegiatan pengabdian. Mitra Pondok Pesantren menentukan jumlah santri yang harus mengikuti kegiatan dan memberikan ijin pelaksanaan kegiatan. Mitra Rumah Darin berbagi pengalaman dan inspirasi dengan santri.

b. Evaluasi pelaksanaan kegiatan. Indikator evaluasi pelaksanaan kegiatan adalah kehadiran, partisipasi, dan kelancaran pelaksanaan kegiatan pengabdian. Target kehadiran peserta mampu dcapai, baik dalam kuantitas maupun ketepatan waktu kehadiran. Santri juga dapat berpartisipasi dengan baik dalam dua kali pertemuan kegiatan pengabdian. Santri sangat antusias dan menikmati kegiatan pengabdian 
yang telah dilaksanakan.

Keberhasilan pelaksanaan kegiatan pengabdian juga tampak pada terlaksananya dua pertemuan tanpa halangan yang berarti.

\section{KESIMPULAN DAN SARAN}

Tim pengabdi telah berhasil melaksanakan kegiatan pengabdian dengan melibatkan dua mitra utama, yaitu pondok pesantren Al Asror dan Rumah Darin Semarang. Santri menjadi peserta utama dalam pelaksanaan kegiatan pengabdian masyarakat ini. Kegiatan pengabdian dapat dilaksanakan dua kali pertemuan, yaitu pada tanggal 23 Juni 2019 dan 7 Juli 2019. Materi yang disampaikan adalah perkembangan financial technology dan pentingnya berwirausaha. Menjadi pemateri adalah tim pengabdi dan owner Rumah Darin. Peserta dapat mengikuti kegiatan pengabdian dengan penuh antusias.

Saran yang dapat diberikan adalah sebagai berikut:

a) Kegiatan pengabdian dapat lebih melibatkan santri yang ada di sekitar kampus UNNES, baik santri yang masih duduk di SMP maupun mahasiswa.

b) Tim pengabdian dapat mengajak mitra lainnya seperti OJK dan pelaku bisnis untuk terus memberikan edukasi dan inspirasi bagi santri.

\section{DAFTAR PUSTAKA}

Ekaningsih, N. (2020). Pelatihan Membangun Kemauan dan Ketertarikan Berpidato Bahasa Inggris bagi Warga Ponpes Satu Atap Nurul Amal Bandungan Kab. Semarang (Issue 024).

Ghofirin, M., \& Karimah, Y. I. (2017). Pengabdian pada Masyarakat Pondok Pesantren Qomaruddin Desa Bungah Gresik Kewirausahaan Santri. Community Development Journal, 1(2), 56-61.

Iman, N. (2016). Financial Technology dan Lembaga Keuangan. Gathering Mitra Linkage Bank Syariah Mandiri, 1-31.

Kardoyo, Muhsin, Fachrurrozie, \& Nurkhin, A. (2018). IbM bagi Santri di Kecamatan Gunungpati Kota Semarang untuk Meningkatkan Minat Berwirausaha. Jurnal Pengabdian Al-Ikhlas, 4(1), 53-65.

Khoirudin, Nurdiyah, D., \& Asmiatun, S. (2017). Peningkatan Kemampuan Membuat Video Animasi Stop Motion bagi Santri Pondok Pesantren Al Ishlah Tugu Semarang.

Mutiah, R. (2015). Peningkatan

Keterampilan Santri di Lingkungan Pondok Pesantren Terpadu Al-Yasini Pasuruan Melalui Konseling Sebaya, Swamedikasi dan Pembuatan Produk Herbal.

Nurkhin, A., Muhsin, Baswara, S. Y., \& Astuti, D. P. (2020). Program Peningkatan Kompetensi Wirausaha Halal Food bagi Santri 
Tahfidz. Jurnal Pengabdian AlIkhlas, 5(2), 107-117.

Solkan, A. (2017). Tantangan Santri Zaman Now. NU Online, 1-5. www.nu.or.id/post/read/84553/tant angan-santri-zaman-now

Wahidah, E. Y. (2018). Pembinaan Masyarakat Berbasis Pesantren Melalui Program Pelatihan Manajemen Qolbu Di Pondok Pesantren Putri Hidayatullah Bojonegoro. Annual Conference on Community Engagement, 886-905.

Wakit, S., \& Huda, H. (2018). Pemberdayaan Santri Pondok Pesantren Tradisional (Pemanfaatan Teknologi Komputer Dalam Pembelajaran Kitab Kuning). Conference on Innovation and Application of Science and Tehnology, September, 125-133.
Zulfikar, R., \& Mayvita, P. A. (2018). Diversifikasi Produk Olahan Berbasis Ikan Patin sebagai Potensi Usaha bagi Panti Asuhan Al Amin dan Sultan Suriansyah Banjarmasin. Jurnal Pengabdian Al-Ikhlas, 4(1), 82-94.

www.nu.or.id/post/read/97640/tantanga n-santri-zaman-now-menurut-khmaruf-amin

iainsalatiga.ac.id/web/santri-harus-siapmenjawab-tantangan-masa-depan/

https://www.dbs.com/spark/index/id_id/ site/pillars/2018-rahasiaperkembangan-fintech-diindonesia-industri-digital-yangsedang-berkembang-pesat.html

https://republika.co.id/berita/ekonomi/k orporasi/18/11/23/pin0bd370asosiasi-adopsi-fintech-indonesiamasih-rendah 